\title{
A Research on the Application of Case Teaching Method in Curric- ulum-Based Ideological and Political Education in College English Course under the Concept of OBE
}

\author{
Hongmei Chen ${ }^{*}$ \\ Zhejiang Wanli University, Ningbo, Zhejiang, 315101, China
}

\begin{tabular}{l} 
ARTICLE INFO \\
\hline Article history \\
Received: 1 April 2021 \\
Revised: 7 April 2021 \\
Accepted: 9 April 2021 \\
Published Online: 16 April 2021 \\
Keywords: \\
Curriculum-based ideological and political \\
education \\
OBE \\
College English course \\
Case teaching design \\
Case teaching method
\end{tabular}

\section{Introduction}

In 2016, Xi Jinping, General Secretary of the CPC Central Committee, pointed out, " "Cultivating People by Virtues' should be regarded as the central task in the field of education, and ideological and political education work should run through the whole process of education and teaching. We should make full use of classroom teaching, regarding it as the main channel to enhance the

\begin{abstract}
Since the idea of "Curriculum-Based Ideological and Political Education" was formally proposed in 2016, it has rapidly become a research hotspot in education reform. Although a large number of relevant studies have focused on the effective paths to curriculum-based ideological and political education in specific courses, there are few studies on how to integrate ideological and political education contents into particular courses under specific educational concepts and by particular teaching methods. Thus, this paper will explore how to improve the teaching effectiveness of curriculumbased ideological and political education in College English course with the OBE concept as the driving force and the case teaching method as the means. Finally, a few thoughts on the application of case teaching method in College English course are offered.
\end{abstract}

affinity and pertinence of ideological and political education. All kinds of courses should go in the same direction as ideological and political theory courses do, forming synergies." [1] Since then, "Curriculum-based Ideological and Political Education", a new education and teaching concept, has been formally proposed and quickly become a research hotspot in the field of teaching reform.

By sorting out the literature on CNKI (Chinese Nation-

\footnotetext{
*Corresponding Author:

Hongmei Chen,
}

Female, master, lecturer,

Research direction: pedagogy and educational psychology;

Zhejiang Wanli University, Ningbo, Zhejiang, 315101, China;

E-mail:363332205@qq.com.

Fund Project: A general project granted by NingBo Education Science Planning in 2020_A Research on the Application of Case Teaching Method in "curriculum-based Ideological and political education" in College English Course under the Idea of OBE (No.: 2020ygh033). 
al Knowledge Infrastructure), it is found that the studies on curriculum-based ideological and political education, conducted by Chinese domestic scholars, mainly focus on four aspects, namely, concept definition, theory construction, values and implementation paths. Although a large number of studies have focused on the effective paths to curriculum-based ideological and political education, there are few researches on how to integrate ideological and political education elements into particular courses, with specific educational concept as the driving force and concrete teaching methods as the means. Therefore, from this perspective, this paper tries to explore how to improve the teaching effectiveness of curriculum-based ideological and political education in College English course, using OBE concept as the driving force and case teaching method as the means.

\section{OBE VS. Curriculum-based Ideological and Political Education}

Outcome- Based Education (OBE) is an idea oriented towards students' learning outcome. ${ }^{[2]}$ This concept requires teachers to design curriculum and teaching process with students' learning outcomes as the orientation. Since its emergence in the 1970s, the concept of OBE has been widely used in many fields, such as engineering certification, basic education, professional degree certification of MBA, business training and so forth.

The concept of OBE makes clear the direction for the teaching design of curriculum-based ideological and political education. In May of 2020, China's Ministry of Education issued the Guidlines for the Curriculum-based Ideological and Political Education Construction in Higher Education, which stated: "To fulfill the fundamental task of cultivating people by virtues, we must integrate shaping values, imparting knowledge and cultivating abilities into course teaching... We should tap the ideological and political education resources contained in all kinds of courses, so as to foster students into socialist builders and successors with the all-round development in morality, intelligence, physique, aesthetics and labor education." ${ }^{[3]}$ In accordance with the Guidelines, College English Curriculum Requirements (2020 Edition) also clearly states: "The objective of EGP (English for General Purpose) course is to increase students' knowledge, broaden their international vision, enhance their comprehensive cultural literacy, and help them build up a correct outlook on world, life and values," and "EGP curriculum should be designed around the basic task-- Cultivating People by Virtues. And the concept and contents of the curriculum-based ideological and political education should be blended into the curriculum ". ${ }^{[4]}$ It can be clearly seen that, based on the College English course learning, students are to become talents with both political integrity and professional competence, which is the students' ultimate learning outcome. Under the guidance of OBE, College English course should emphasize this learning outcome, and design teaching activities based on it, thus integrating the ideological and political education objectives into curriculum objectives.

\section{Case Teaching Method VS. Curricu- lum-based Ideological and Political Education}

Up to now, the scholars at home and aboard still have not reached a consensus on the definition of "Case". Sun Junye argued that a case is a thought-provoking typical educational story which is narrated in a real educational situation, containing certain educational truths. ${ }^{[5]}$ Similarly, these scholars have not formed a unified view on the definition of "Case Teaching Method". As Zheng Jinzhou put it, Case Teaching Method can be defined as a teaching method that guides students to discuss some special situations by describing a specific educational situation ${ }^{[6]}$. In this paper, the author, from the perspective of humanities and social sciences, will adopt the concepts of "Case" and "Case Teaching Method" in a broad sense.

"Case teaching method" is consistent with the concept of "implicit ideological and political education". Albert Bandura, an American well-known psychologist, put forth social learning theory, which argues that the vast majority of people acquire their behavior by observing others demonstrating their behavior. By observing others' exemplary behavior, people will be deeply imprinted on their minds by the memory on how to behave, which will become, in the future social situations, the guide of learning new behavior ${ }^{[7]}$. What observation learning theory advocates has significant implications for the current ideological and political education? It highlights the great power of the models and advocates the role of models being brought to full play in a permeable way. In the context of "curriculum-based ideological and political education" in College English course, teachers should be proficient at using case teaching method, giving full play to the power of models in cases, and imperceptibly improving the ideological and political literacy of learners. Thus, social learning theory has provided a sound rationale for the application of case teaching method in curriculum-based ideological and political education.

\section{Case Teaching Design}

The report of the 18th National Congress of the Com- 


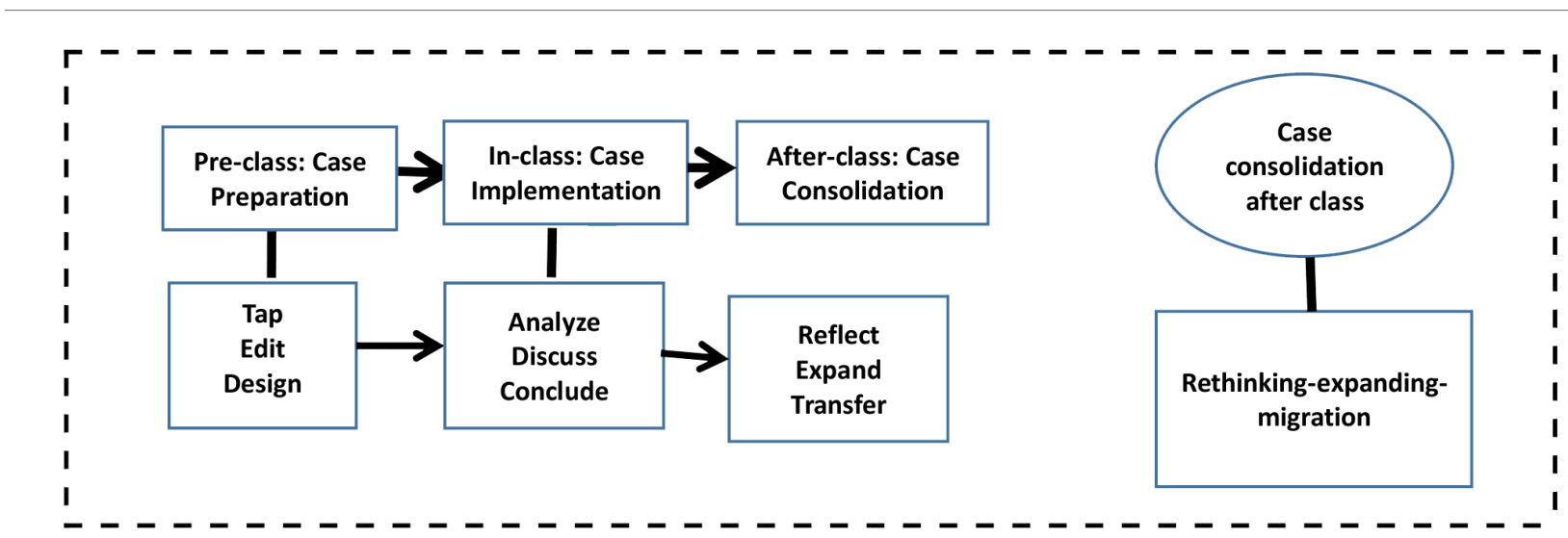

Figure 1. Case Teaching Model

munist Party of China proposed that "Cultivating People by Virtues" should be regarded as the fundamental task of education to cultivate socialist builders and successors with all-round development in morality, intelligence, physique, aesthetics and labor education, which firmly answered the fundamental questions of education: "Who are cultivated?, How are they cultivated? And for whom are they cultivated". Based on the concept of OBE and the fundamental task of "Cultivating People by Virtue", the author, driven by the ultimate learning outcome..."students becoming English talents with both moral integrity and professional competence", has attempted to design a model for case teaching process, thus guiding the curriculum-based ideological and political education in College English course. The model can be seen in Figure 1.

\subsection{Case Preparation}

Digging out rich theme-related cases is the first and foremost step of implementing case teaching activities. As mentioned earlier, in a broad sense, a case usually refers to a thought-provoking educational story that contains certain educational truths and can shape personal values to a certain extent. With this interpretation, the author discovered that many educational stories are covered in the textbook New Progressive College English Integrated Course. For instance, Unit 1 of Book I takes "chasing dreams" as the theme, and presents three educational cases, such as the inspiring story about the deaf man Robbie Wilde becoming a successful DJ in the Text Deaf DJ, the true story of Filipa, a cleaner, successfully transforming from a refugee to a college student in Reading 1 Janitor Filipaj, the Dream Pursuer, and another encouraging story about Yu Minhong pursuing his Dream and starting his own business in Reading 2 From the 'American Dreams' to a Chinese Dream. Additionally, a large number of educational stories are available online. Digging out an abundance of educational cases from our textbooks and the
Internet can provide rich teaching materials for the curriculum-based ideological and political education in College English course.

Editing the texts of various case stories will make cases much more targeted and more effective in enhancing students' ideological and political literacy. An educational case can also be interpreted as a typical statement of events with various meanings that people experience in real life. An educational case is typically composed of four elements, namely, real and complex situation, typical events, multiple problems and typical solutions. However, a large number of stories available in our textbooks and even online are not complete and hard to be directly applied in our teaching. Thus, teachers need to edit the texts of cases, changing the sequence of events, adding the background information, and even creating some plots. In the case "Deaf DJ", the author adds the description of situation, i.e, the description of Chinese Dream.

Designing a case is critical to case teaching. Typically, the contents of a case involve background information, objectives, process, results, and thoughts. In accordance of this typical content framework, the author, driven by students' learning outcomes, map a case into a "five-element" frame, which is composed of background, title, learning objectives, text, and a series of questions. Here, it's worth noticing that ideological and political education objectives are integrated into learning objectives, which are composed of knowledge objectives, skill objectives and value objectives. A series of questions are designed around a specific goal or central topic. These questions are usually progressive ones which are designed from easy to difficult, progressive and interlinked. They are well-targeted, enlightening, progressive and thought-provoking so that students' thinking can be driven to the summit and the students can be aware of the important values the case implies. The idea of designing progressive questions still aligns with implicit ideological and political education. 


\subsection{Case Implementation}

Classroom is the main position of implementing case teaching. Analyzing and discussing cases is the central link of case teaching.

The Dialogue-based teaching is the main tool for teachers to analyze the case. This teaching model proposed by Socrates, a prominent educator in ancient Greece, enlightens students' thinking through continuous questioning as well as progressive analysis, and gradually deepens students' understanding, so that the problems can be finally solved. ${ }^{[8]}$ With the context of College English teaching, by continuous dialogues about the case, it is helpful for teachers to pushing students' thinking to a climax, helping students finally achieving the dual learning goals of English language skills acquisition and value enhancement. In analyzing the case "Deaf $D J$ ", the author, guided by the learning outcome---students finally master the important qualities of coming true their dreams, questions the students progressively this way: "What is anything special about Robbie Wilde?" "What factors cause him to be deaf?" "What dream did he have as a deaf man?" "How did he achieve his dream?" "What qualities make him a successful dreamer? In the process of making dialogues, the author analyzes the core language points and content in the case, and the students deepen their understanding step by step, and gradually form a resonance with the protagonist of the case---Robbie Wilde. Finally, they naturally realize the excellent qualities, such as diligence, perseverance, commitment to serve people, passion and so on, which are vital to coming true our dreams.

Creating a relaxed atmosphere for discussion is also of great importance in the process of case teaching, a series of questions designed by the teacher before the class can be used as a scaffold to assist the students conducting their group discussions and report the results. The teacher can make a summary on the basis of the students' reports. The author summarized the case "Deaf $D J$ " as follows: As a deaf man, Robbie Wilde sets a good example for other young people in chasing their dreams. In the pursuit of our dreams, we need to have passion, to work hard, to focus on one thing, to be persistent, to have creative ideas, to serve people, to be good at one thing and to be pushed by someone, thus guiding students' values shaping.

\subsection{Case Consolidation}

After-class consolidation is an important step for students to internalize what the case teaches us. Internalization refers to the idea of being consistent with others' ideas and viewpoints. The new ideas are combined with one's original ideas and beliefs to form a unified attitude system. Internalization is a cognitive system which is accomplished through assimilating and adapting to what one sees, hears and ponders. Internalization plays a vital role in guiding moral education. In the context of College English teaching, the students can consolidate and internalize the values imparted by the case in various ways, like writing reflection logs, videotaping the cases, creating similar cases, case continuation and so forth.

Reflection logs refer to making use of a relatively fixed template and relatively short time to sort out the "touching" things of the day and write down one's thoughts, supplementing or updating one's ideas or concepts, which is conducive to enhancing one's moral values. Based on the case "Deaf DJ", the author constructed a reflection log template consisting of three parts: 1) what did you previously know about deaf people? ; 2) What new information did you learn about deaf people from this case? ; 3) How do you relate this case to your real life? Through further reflection on the case, students connect the values imparted by the case with their original beliefs, and dwell on what good qualities they should cultivate to realize their dreams, thus expanding the learning results of this case and transferring the values from the protagonist of the case to the learners themselves. Similarly, students reproduce or recreate cases by making videos or writing, which further strengthens students' internalization of ideological and political education elements.

\section{Thoughts}

With the guidance of OBE, the application of case teaching method in the curriculum-based ideological and political education of College English courses is of profound significance to the ultimate goal of "cultivating people by virtue". Teaching practice has proved that the effectiveness of imparting knowledge and cultivating people could be greatly improved through designing and analyzing cases to bring out the ideological and political education elements contained in the cases in a hidden way. However, there are still some areas that need to be deeply considered.

\subsection{Create Case Base}

For case teaching method, case is the core material of teaching, without cases, case teaching will be "a brick without straw". Case teaching method has been widely used in law, medicine, business and other professional disciplines since it was proposed. However, it is still in its infancy for College English as a general language course, and there are a limited number of cases with English as the carrier that contain rich ideological and political edu- 
cation elements. Thus, it is of great necessity for teachers to dig out sufficient English cases from the Textbooks and the Internet, analyzing, editing and integrating them so as to build a shared high-quality case base.

\subsection{Strengthen Case Design}

Case design is the key to fulfilling the dual goals of language knowledge reserve and ideological and political education. The key to case design is whether the design can engage the students in the discussion, whether a series of questions embedded in the case can arouse students' indepth thinking, ultimately improving their values so as to realize the implicit integration of ideological and political education elements into the course learning. Thus, it is of great vitality to strengthen teachers' ability to analyze cases, their perception of ideological and political education elements and their ability to control the difficulty of the progressive questions, which will surely optimize the effectiveness of case design.

\subsection{Optimize Assessment Mechanism}

Since case teaching method is applied as a new teaching method in the curriculum-based ideological and political education of College English course, the content, types and ways of course assessment should be adjusted accordingly. The assessments for College English course in the context of "curriculum-based ideological and political education" should focus on language knowledge, skills and core literacy and a three-dimensional assessment mechanism should be established, integrating diagnostic assessment, formative assessment and summative assessment.

\section{Conclusion}

Although College English Curriculum Requirements (2020 Edition) has clearly stated that the College English curriculum should be integrated into the system of curriculum-based ideological and political education, playing an important role in fulfilling the fundamental task of
"Cultivating People by Virtues", yet without the driving power of specific education concept and particular teaching method, the curriculum-based ideological and political education in College English course has achieved little in cultivating people. Therefore, the author, driven by OBE, applies the case teaching method in the curriculum-based ideological and political education of College English course, orients the case design and case teaching process towards students' ultimate learning outcome and also put forwards some relevant thoughts, thus provides a reference for other teachers in implementing case teaching method to enhance the learners' ideological and political literacy.

\section{References}

[1] Xi Jinping. Speech on the 95th Anniversary of the Founding of the CPC [M]. Beijing: People's Publishing House, 2016.

[2] Wang Zhongmin, Qiao Huaying, Ma Yongqing. The Implications of OBE on the Curriculm Reform [J]. Shandong Higher Education, 2019,7 (6).

[3] China's Ministry of Education. the Guidlines for the Curriculum-based Ideological and Political Education Construction in Higher Education. China Education News Network, 2020 (5).

[4] The National Administry Committee on Teaching Foreign Language in Higher Education under the Ministry of Education. College English Curriculum Requirements $[\mathrm{M}]$. Beijing: Higher Education Press, 2020.

[5] Sun Junye. Case teaching [M]. Tianjin: Tianjin Education Press, 2004.

[6] Zheng Jinzhou. The Guide to Case Teaching [M] Shanghai: East China Normal University Press, 2000

[7] Albert Bandura. Social Learning Theory [M]. Beijing: China People's University Press, 2016.

[8] Tian Xin. Classroom Generation of Socratic Dialogue-based Teaching Model [J]. Journal of Nanchang Institute of Education, 2014(02). 